Anja Gabrielsen

Universitetet i Sørøst-Norge

DOI: http://dx.doi.org/10.5617/adno.4803

\title{
Hvordan kan en forskningstilnærming bidra til å vektlegge lærerens stemme ved studie av utdanning for bærekraftig utvikling?
}

\section{Sammendrag}

I denne metodologistudien drøftes anvendelse av konstruktivistisk grounded theory på et datamateriale med intervjuer av larere med erfaring i utdanning for bœrekraftig utvikling (UBU). Siden flere studier peker på et gap mellom målene for UBU og hva som foregår i skolene, kan en tilncerming hvor lcerernes stemmer vektlegges gi et viktig bidrag inn i forskningsfeltet. Både datainnsamling med semi-strukturerte intervju og den innledende kodingen bidro til å løfte fram lerernes perspektiv, mens den fokuserte kodingen ble tydeligere preget av forskerens valg, og i sterkere grad gjenspeiler forskerens stemme. Samtidig bidrar den konstant komparative analysen mellom rådata, koder og kategorier til å holde tolkningene ncer opp til det som kom fram i intervjuene. Det omfattende kvalitative datamaterialet reduseres og kategoriseres gjennom analyseprosessene, og sentrale kategorier ses i sammenheng som et begynnende rammeverk for videre praksisncer forskning og utvikling. I Stortingsmelding 28 om fornyelse av Kunnskapsløftet vektlegges både opplæringssystemets ansvar for å gi elevene kompetanse for en bærekraftig utvikling og et utviklingsorientert lererkollegium som reflekterer over forskningsbasert kunnskap kombinert med erfaringer fra egen praksis (Meld. St. 28, 2015-2016). Denne artikkelen viser hvordan en forskningstilncerming kan bidra til å framskaffe kunnskap med utgangspunkt i praksis, innenfor et nytt satsingsområde i skolen.

Nøkkelord: forskning på praksis, konstruktivistisk grounded theory, utdanning for bærekraftig utvikling

\section{Emphasizing the teacher's voice through a research approach in education for sustainable development}

\section{Abstract}

This study of methodology discusses an application of constructivist grounded theory on data from interviews with teachers experienced in education for sustainable development (ESD). Since several studies indicate a gap between 
the objectives of ESD and its implementation in schools, an approach where the teachers' voice is emphasized could make an important contribution to this field of research. The data collection with semi-structured interviews and the initial coding both helped maintaining a focus on the teachers' perspective, while the focused coding was a process clearly marked by the researcher's choices. At the same time, the constant comparative analysis of the raw data, codes and categories keeps the interpretations close to the information in the interviews. The comprehensive qualitative data is reduced and systematized through the processes of analysis, in which key categories are seen in context as an initial framework for further research and development of practice. In White Paper no 28 concerning the renewal of the national curriculum, the government emphasizes the educational system's responsibility to provide students with competences for a sustainable development, together with a development-oriented teacher staff able to reflect on research-based knowledge in combination with experiences from their own practice (Meld. St. 28, 2015-2016). This article indicates ways in which a research approach can contribute to knowledge production based on practice, within a new focus area in school.

Keywords: research on practice, constructivist grounded theory, education for sustainable development

\section{Innledning}

Utdanning for bærekraftig utvikling (UBU) har de siste årene blitt trukket fram som et viktig tema som skal styrkes i læreplanen og jobbes med både i de ulike fagene og gjennom en tverrfaglig tilnærming (Meld. St. 28, 2015-2016; NOU 2015:8, 2015). Denne vektleggingen er et resultat av flere nasjonale og internasjonale initiativ, blant annet FNs tiår for satsing på UBU (UNESCO, 2005). Selve begrepet bcerekraftig utvikling kan tolkes ulikt og er omdiskutert (Dobson, 1996; Sinnes, 2015), og det er store forskjeller i hvordan det implementeres i ulike lands utdanningssystem (Blum, Nazir, Breiting, Goh \& Pedretti, 2013). Undervisning knyttet til miljøutfordringer og bærekraftig utvikling er krevende siden den involverer flere fag, har normative problemstillinger med handlingsaspekt og utfordrer både lærernes kompetanse og måten vi organiserer undervisningen på i skolen (Sinnes, 2015; Stevenson, Brody, Dillon \& Wals, 2013). Denne kompleksiteten fører til at mange lærere er usikre på hva UBU innebærer og hvordan denne undervisningen bør gjennomføres (Borg, Gericke, Höglund \& Bergman, 2012; Laurie, Nonoyama-Tarumi, Mckeown \& Hopkins, 2016). Flere studier peker også på et gap mellom politiske mål for UBU og hva som foregår ute i skolene (Breiting \& Wickenberg, 2010; Stevenson, 2007). Det trengs mer forskning på UBU-praksis og på læreres erfaringer (Blum et al., 2013; McNaughton, 2012; Reid \& Scott, 2013; Stevenson, 2006). Siden fagfeltet ikke 
er tydelig definert, kan det være godt egnet for en studie som er lydhør overfor lærernes oppfatninger og erfaringer. Dette kan plasseres i en kvalitativ forskningstradisjon hvor sosiale eller menneskelige prosesser undersøkes, hvor det forsøkes å få fram deltakernes perspektiv og gi bidrag til mer helhetlige bilder av virkeligheten (Creswell, 2013; Denzin \& Lincoln, 2011; Postholm, 2004).

Denne artikkelen undersøker hvordan forskningstilnærmingen konstruktivistisk grounded theory (Charmaz, 2014) kan anvendes for å analysere intervjuer av lærere der de reflekterer over erfaringer med UBU. Det gis en grundig beskrivelse av den konkrete analysen og en synliggjøring av dilemmaer som oppstår i prosessen. Artikkelen problematiserer og diskuterer konkret bruk av forskningsmetoder, og kan karakteriseres som en drøfting av metodologi (Silverman, 2011). Målet med studien er å vise hvordan forskningstilnærmingen kan bidra til å få fram nye, praksisnære perspektiv som kan brukes i utvikling av undervisning og videre teoridanning og forskning. I Stortingsmelding 28 om fornyelse av Kunnskapsløftet står det: «Et utviklingsorientert lærerkollegium reflekterer over forskningsbasert kunnskap kombinert med erfaringer fra egen praksis» (Meld. St. 28, 2015-2016, s. 24).

Studien har følgende problemstilling: Hvordan kan bruk av konstruktivistisk grounded theory bidra til praksisncer forskning i UBU? Konkrete forskningsspørsmål er: Hvordan bidrar forskningstilnærmingen til (i) nærhet til lærernes utsagn, (ii) å skaffe oversikt og systematisere, og (iii) praksisnær teoridanning? Først presenteres en kort beskrivelse av konstruktivistisk grounded theory, deretter beskrives og forklares analyse av eget datamateriale. Til sist drøfter jeg resultatene og vurderer tilnærmingens bidrag til praksisnær forskning i UBU.

\section{Konstruktivistisk grounded theory som forskningstilnærming}

Grounded Theory av Barney Glaser og Anselm Strauss (Glaser \& Strauss, 1967) kom som en reaksjon på den tids diskusjon innen samfunnsvitenskapelig (sosiologisk) forskning hvor spenningene mellom kvantitativ og kvalitativ forskning var store, og hvor kvalitativ forskning ble kritisert for ikke å være vitenskapelig nok. Glaser og Strauss var kritiske til den deduktive tilnærmingen, der teoretiske perspektiv ble brukt som utgangspunkt for forskning på praksis, og til den induktive sosiologiske forskningen som var lite teoretisert (Charmaz, 2014). Grounded theory representerer et systematisk alternativ til kvantitativ forskning og til en enten teoridrevet eller induktiv kvalitativ forskning. Glaser og Strauss skriver: "We seek in this book to further the systematization of the collection, coding, and analysis of qualitative data for the generation of theory» (1967, s. 18). Glaser og Strauss vektla en prosess med observasjon, refleksjon og konstant komparativ analyse med ønske om å generere teori. Fokuset for denne formen av kvalitativ forskning ble flytta fra deskriptive studier til forklarende teoretiske rammeverk som kan bidra til mer abstrakt konseptuell forståelse av fenomenet som undersøkes (Charmaz, 2014). Glaser og Strauss kom fra ulike tradisjoner, med statistisk positivisme, symbolsk interaksjonisme og pragmatisme (Alvesson 
\& Sköldberg, 2008; Charmaz, 2014), noe som kan ha bidratt til at metodologien går på tvers av skiller både mellom deduktiv og induktiv forskning og mellom kvantitativ og kvalitativ forskning. Glaser og Strauss har videreutviklet teorien i hver sin retning. Glaser kritiserte Strauss og den nye samarbeidspartneren Corbin for å være for opptatt av prosedyrer og strukturer. Han selv forsvarte en klassisk grounded theory, med åpen utforsking hvor teori ikke tvinges fram, men framkommer ved hjelp av konstant komparativ metode (Creswell, 2013). Strauss og Corbin har på sin side utviklet en versjon som kjennetegnes ved en formell analysestruktur, og som i stadig større grad inkluderer forskerens forforståelse noe den tidlige, mer klassiske teorien ikke vektlegger (Charmaz, 2014; Corbin \& Strauss, 2008).

I Charmaz' konstruktivistiske versjon av grounded theory vektlegges mer eksplisitt forskerens forforståelse og behovet for å synliggjøre tolkingen. Hun anbefaler forskeren å se på sin tolking og sitt perspektiv som ett av flere:

What you see in your data relies in part upon your prior perspectives. Rather than seeing your perspectives as truth, try to see them as representing one view among many. That way, you may gain more awareness of the concepts that you employ and might impose on your data (Charmaz, 2014, s. 132).

Det konstruktivistiske kunnskapssynet, hvor kunnskap ikke er gitt og kan overføres men er noe som konstrueres i møte mellom mennesker (Postholm, 2010), er sentralt i Charmaz' versjon av metodologien, og hun skriver: «Data do not provide a window on reality. Rather, the "discovered" reality arises from the interactive process and its temporal, cultural, and structural contexts» (Charmaz, 2000, s. 524). Også Strauss og Corbin, og spesielt Corbin, har i sine senere utgaver av metodebøker i grounded theory beveget seg over i en tolkende tankegang som tar mer hensyn til forforståelse (Charmaz, 2014; Corbin \& Strauss, 2008). Den andre opphavsmannen, Glaser, har derimot beholdt perspektivet om at dataene representerer objektive fakta som forskeren kan bruke for å «oppdage» teori (Charmaz, 2014).

I de ulike variantene av grounded theory brukes litt forskjellige analysetilnærminger, men alle benytter flere kodingsfaser, kategorisering, memoskriving og gjentakende sammenlikning mellom de ulike delene (Charmaz, 2014; Corbin \& Strauss, 2008; Glaser \& Strauss, 1967). Flere av disse grunnleggende analysetilnærmingene har hatt stor innvirkning på kvalitativ forskning, og det er mange forskere som benytter disse uten at de knytter sin forskning til grounded theory (Postholm, 2010). 


\section{Anvendelse av konstruktivistisk grounded theory}

\section{Utvalg og datainnsamling}

Forskningsdeltakerne er valgt ut blant lærere som har gjennomført undervisning innen miljø og bærekraftig utvikling og deltatt i Den naturlige skolesekken, et landsdekkende, statlig initiativ for å øke fokuset på utdanning for bærekraftig utvikling (Sandås \& Isnes, 2015; Scheie, 2014). Åtte lærere fra fem barneskoler og to ungdomsskoler var med i undersøkelsen, og de hadde gjennomført undervisningen i 6.-9. klasse. Skolene ligger i småbyer og rurale strøk, ingen er plassert i en større by. Skolene er middels til store skoler etter norsk målestokk.

Semi-strukturert intervju ble valgt som datainnsamlingsmetode for å undersøke lærernes erfaringer og refleksjoner knyttet til gjennomført undervisning og utdanning innen bærekraftig utvikling generelt. Det ble utarbeidet en spørsmålsguide som ble brukt som utgangspunkt for intervjuene. Etter første intervju ble det gjort noen små endringer i spørsmålsguiden, men også etter de påfølgende intervjuene ble det vurdert om spørsmålene var hensiktsmessige eller om noe burde endres for å treffe forskningsspørsmålene på en bedre måte. Underveis i intervjuene ble det stilt ulike oppfølgingsspørsmål knyttet til hvilken retning samtalen tok. Intervjuene hadde en varighet på cirka en time, og det ble gjort lydopptak av dem. Det ble underveis og etterpå skrevet ned små teoretiske ideer, memoer, knyttet til interessante funn og sammenhenger. I tillegg ble det skrevet logg for mer praktiske erfaringer.

\section{Analyse}

For å synliggjøre hvordan jeg har kommet fram til resultatene i denne studien, beskrives analyseprosessen fra transkribering, gjennom koding og kategorisering og fram til begynnende modellering og teoridanning.

\section{Transkribering}

Intervjulydfilene ble transkribert ordrett, og underveis ble det skrevet memoer over tanker rundt kategorier og sammenhenger. Det ble også notert ned mer personlige erfaringer med intervjusituasjonen, min rolle og deltakernes reaksjoner. Etter avsluttet transkribering skrev jeg en kort oppsummering til hvert intervju.

\section{Innledende koding}

Intervjuene ble kodet gjennom innledende koding (Charmaz, 2014) eller åpen koding som er en mer tradisjonell benevning av denne aktiviteten (Corbin \& Strauss, 2008). Jeg leste grundig gjennom intervjuene og kodet setning for setning der meningsinnholdet var stort, eller avsnitt der det var mindre relevant innhold knyttet til mitt forskningsfokus. Gjennom innledende koding studerte jeg datafragmenter som ord, setninger og utsagn for å finne ut hva de handlet om og om de var viktige for analysen. 
Kodene som er benyttet i analysen er basert på lærernes egne ord (in-vivo koding), enten enkeltord, noen få ord eller korte sitater. For å holde kodene enkle er innholdsrike, lengre setninger eller avsnitt komprimert ned ved å lage en kode som betegner innholdet selv om den ikke er ordrett. Kodingen skal både fange opp interessant mening, men også fungere som en systematisering og reduksjon av det store kvalitative datamaterialet, for å gjøre det mulig å se sammenhenger i hele materialet. Underveis i kodingen sammenliknet jeg de ulike kodene med hverandre for å se om de beskrev samme fenomen og dermed kunne få samme navn. Tidlig i kodingsfasen begynte jeg også å konstruere forslag til kategorier for systematisering av kodene. Disse ble notert ned på memos.

I tabell 1 er det presentert eksempler på avsnitt fra intervjuene (rådata) sammen med innledende koder. Rådata fra de transkriberte intervjuene tolkes og ender opp i en innledende kode. For eksempel kan rådataene fra intervju med lærer nr. 2: «Jeg tror det er viktig å begynne der de er kjent. (...) skal en ha mye utbytte av det tror jeg faktisk det er best å begynne her» kodes som: «Begynne der de er kjent». De innledende kodene ble skrevet i høyre marg ved siden av de aktuelle setningene på papirutskrifter av intervjuene.

Tabell 1. Eksempler på rådata og innledende koder

\begin{tabular}{|c|c|}
\hline Rådata & Innledende koder \\
\hline \multicolumn{2}{|l|}{ (Intervju nr. 2) } \\
\hline Jeg tror det er viktig å begynne der de er kjent. (...) skal en & Begynne der de er kjent \\
\hline ha mye utbytte av det tror jeg faktisk det er best å begynne & Mer utbytte \\
\hline her. Og etter hvert utvide området i større og større sirkler. & Utvide området \\
\hline Men vi må bare gjøre sirklene større og større, gå lenger og & \\
\hline lenger ut. Og da mener jeg det blir lettere og lettere å forstå & Lettere å forstå \\
\hline og elevene skjønner mer av sammenhengene. Hvis de hører & \\
\hline om endringer her i området vil de lettere skjønne at det & Lokalt \\
\hline skjer mange endringer i andre områder også. & Andre områder også \\
\hline \multicolumn{2}{|l|}{ (Intervju nr. 3) } \\
\hline Det er vagt. At det kan være litt samfunnsfag, og litt & Er vagt \\
\hline naturfag og litt... at man skal dele godene for ikke å & Forskjellige fag \\
\hline overforbruke, og så er det; hvem skal ta ansvar for den & Overforbruk \\
\hline undervisninga? Og så blir det bare mellom alle stolene. Det & Ansvar for undervisning \\
\hline er litt i naturfag, og det er litt i samfunnsfag, men det er så & Faller mellom stolene \\
\hline \multicolumn{2}{|l|}{ (Intervju nr. 6) } \\
\hline Den største utfordringen er at elevene ofte uttaler; ja, men & \\
\hline da lever ikke vi! De klarer ikke å se veldig langt frem i tid. & Framtid \\
\hline (...) Det er det med forståelsen, og det er veldig vanskelig å & Forståelse \\
\hline konkretisere det på noe vis. Du kan lage noen fine & Vanskelig å konkretisere \\
\hline statistikker og bilder, men jeg tror ikke de klarer helt å & Klarer ikke forholde seg til det \\
\hline forholde seg til det. Det blir litt science fiction for de. Så & Blir science fiction \\
\hline jeg tenker den største utfordringa er å klare å gjøre det reelt, & Gjøre det reelt og konkret \\
\hline $\begin{array}{l}\text { eller konkret nok for de, og få de til å kunne klare å se fram } \\
\text { der. }\end{array}$ & Framtid \\
\hline
\end{tabular}




\section{Fokusert koding}

Etter at datamaterialet var kodet gjennom innledende koding, gjennomgikk jeg det på nytt for å finne fram til de mest brukte eller sentrale kodene. Denne andre kodingsfasen kaller Charmaz (2014) fokusert koding, og den skal påskynde analysen gjennom utvalg og fokusering. Hvert intervju har fått mellom $50 \mathrm{og}$ 100 forskjellige innledende koder. Noen koder går igjen i liknende former i alle intervjuene, mens andre nevnes kun én gang i ett intervju. Utvalget av hvilke koder som vurderes som sentrale tas på bakgrunn av at de gjentas mange ganger, eller at de vurderes som viktige selv om de ikke har høy frekvens. Denne vurderingen baseres på en forforståelse fra UBU-teori og kjennskap til rådataene og konteksten i intervjuene. Eksempler på koder som ble valgt ut på grunn av høy frekvens, er naturglede, ncert, oppleve at det nytter og ledelse. Eksempler på koder som ble valgt ut på grunn av sin sentrale betydning, er økonomi og handlingskompetanse. Det er ikke et skarpt skille mellom koder med høy frekvens og koder som er spesielt viktige; mange koder er begge deler. Noen av kodene som har høy frekvens, men som ikke er viktige for forskningsarbeidet, blir ikke valgt ut som fokusert kode. I denne fasen bruker jeg kodeutvalget til å sile, sortere og analysere store mengder data for å finne hvilke koder og foreløpige kategorier som er av størst analytisk betydning.

I tabell 2 er det presentert eksempler på innledende og fokuserte koder.

Tabell 2. Eksempler på innledende koder og fokuserte koder

\begin{tabular}{|l|l|}
\hline Innledende koder & Fokuserte koder \\
\hline (Intervju nr. 2) & Gjøre nært \\
Begynne der de er kjent & Læringsutbytte \\
Utvide området & Lokal - regional - global \\
Lettere å forstå & Sammenhenger \\
Lokalt & Lokal - regional - global \\
Andre områder også & Sammenhenger \\
\hline (Intervju nr. 3) & Læreplan \\
Er vagt & Flere fag \\
Forskjellige fag & UBU tema / perspektiv \\
Overforbruk & Læreplan \\
Ansvar for undervisning & Læreplan \\
Faller mellom stolene & Læreplan \\
Liten del av fagene & \\
\hline (Intervju nr. 6) & Fortid - nåtid - framtid \\
Framtid & Sammenhenger \\
Forståelse & Sammenhenger / Konkretisere \\
Vanskelig å konkretisere & Konkretisere / Gjøre nært \\
Klarer ikke forholde seg til det & Konkretisere / Gjøre nært \\
Blir science fiction & Konkretisere / Gjøre nært \\
Gjøre det reelt og konkret & Fortid - nåtid - framtid \\
Framtid &
\end{tabular}

De innledende kodene tolkes og sammenliknes og ender opp i færre og fokuserte koder. Som eksempel på denne tolknings- og vurderingsprosessen kan den innledende koden «begynne der de er kjent» fra intervju nr. 2, plasseres sammen 
med andre liknende innledende koder i den fokuserte koden «gjøre nœrt». På samme måte vurderes og plasseres de innledende kodene «lettere å forstå» fra intervju nr. 2 og «forståelse» fra intervju nr. 6 i den fokuserte koden «sammenhenger».

Den fokuserte kodingen endte opp med 17-25 sentrale koder for hvert av de åtte intervjuene. Disse ble sammenliknet, modifisert, slått sammen eller utvidet gjennom den komparative analyseprosessen (Charmaz, 2014; Glaser \& Strauss, 1967). Resultatet av den fokuserte kodingen endte opp i noen foreløpige kategorier som er sentrale for innholdet i intervjuene og viktige for videre analyse (tabell 3). Under arbeidet med konstruering av kategoriene oppstod det en slags metning etter gjennomgang av fokuserte koder fra seks intervju. Så de to siste intervjuene tilførte ikke noe spesielt nytt inn i konstruksjonen av kategorier, bare en viss justering.

Tabell 3 viser sammenhengen mellom fokuserte koder og foreløpige kategorier. Fokuserte koder som for eksempel konkretisere, visualisere, gjøre ncert; utforsking, praktiske aktiviteter; samarbeid med lokale personer er alle lagt inn i en foreløpig kategori som kalles «konkret og autentisk». Flere av kategoriene utmerket seg som sentrale allerede under gjennomføring og transkribering av intervjuene, og er nevnt på memoer tidligere i forskningsprosessen.

Tabell 3. Oversikt over fokuserte koder og foreløpige kategorier konstruert etter koding og videreutvikling av memoer

\begin{tabular}{|c|c|}
\hline Fokuserte koder & Foreløpige kategorier \\
\hline Utdanning for bærekraftig utvikling & \multirow{3}{*}{ Kompetanse } \\
\hline Lokal læringsarena, nærmiljø & \\
\hline Lærerutdanning & \\
\hline Generell læreplan, læringsutbytte & \multirow{2}{*}{ Prioritering } \\
\hline Læreplan for fag, læringsutbytte & \\
\hline Historie, samfunn & \multirow{9}{*}{ Belyse ulike bærekraftsperspektiv } \\
\hline Natur & \\
\hline Miljø & \\
\hline Økonomi & \\
\hline Flere fag & \\
\hline Fortid - nåtid - framtid & \\
\hline Lokal - regional - global & \\
\hline Gå i dybden & \\
\hline Sammenhenger & \\
\hline Konkretisere, visualisere, gjøre nært & \multirow{3}{*}{ Konkret og autentisk } \\
\hline Utforsking, praktiske aktiviteter & \\
\hline Samarbeid med lokale personer & \\
\hline Elevpåvirkning & \multirow{3}{*}{ Mulighet for handling } \\
\hline Se/oppleve at det nytter & \\
\hline Handlingskompetanse, læringsutbytte & \\
\hline Følelser, bry seg om, ansvar & \multirow{2}{*}{ Affektiv } \\
\hline Naturglede & \\
\hline
\end{tabular}




\section{Memo}

Underveis i forskningsprosessen har jeg skrevet memoer som kan fungere som bindeledd mellom deskriptiv kodingsanalyse, kategorisering og teoridanning. Spesielt under arbeidet med fokusert koding dukket det opp ideer knyttet til hvordan ulike koder er forbundet med hverandre og hvilke hierarkiske sammenhenger som kan konstrueres. Et eksempel på en memo skrevet ned under den fokuserte kodingen: «Det er to betydninger av samme fokuserte kode: Elever kan påvirke: 1) Elever kan påvirke undervisningen - elevinitiert undervisning, og 2) Elever føler de kan påvirke og bidra til en bærekraftig utvikling, og oppleve at det nytter. Koden må deles og settes i riktig sammenheng.» Memoskrivingen gjorde at jeg begynte analyse av data og koder allerede tidlig i forskningsprosessen, og har bidratt til å fange opp tanker om sammenhenger og dermed påvirket kategoriseringen.

\section{Sammenhenger mellom kategorier og begynnende teoridanning}

Under analyse av sammenhenger mellom innledende koder, fokuserte koder og foreløpige kategorier var det to hovedretninger som utmerket seg. Den ene (A) var lærernes argumentasjon for hvorfor de mener bruk av nærmiljø er viktig i utdanning for bærekraftig utvikling. Følgende fire kategorier danner grunnlag for denne retningen: 1 . belyse ulike UBU-perspektiv, 2. konkret og autentisk lcering, 3. mulighet for handling, og 4. affektiv påvirkning. Den andre hovedretningen (B) var lærernes oppfatninger av utfordringer og barrierer knyttet både til UBU og til bruk av nærmiljøet som læringsarena. De to kategoriene som danner grunnlag for denne retningen er: 1. prioritering og 2. kompetanse. En hovedkategori som binder retningene A og B sammen, er bruk av nærmiljø som læringsarena i UBU. Dette kan settes opp i en modell som vist i figur 1. Lærernes argumentasjon for bruk (A) og deres oppfatninger av utfordringer og barrierer (B) danner et praksisbasert rammeverk som kan bidra til å forstå og utvikle praksis. Modellen og funnene den er basert på, videreutvikles og drøftes med bakgrunn i utdanningspolitikk og fagdidaktisk teori i en studie av nærmiljøet som læringsarena i UBU (Gabrielsen \& Korsager, under utgivelse).

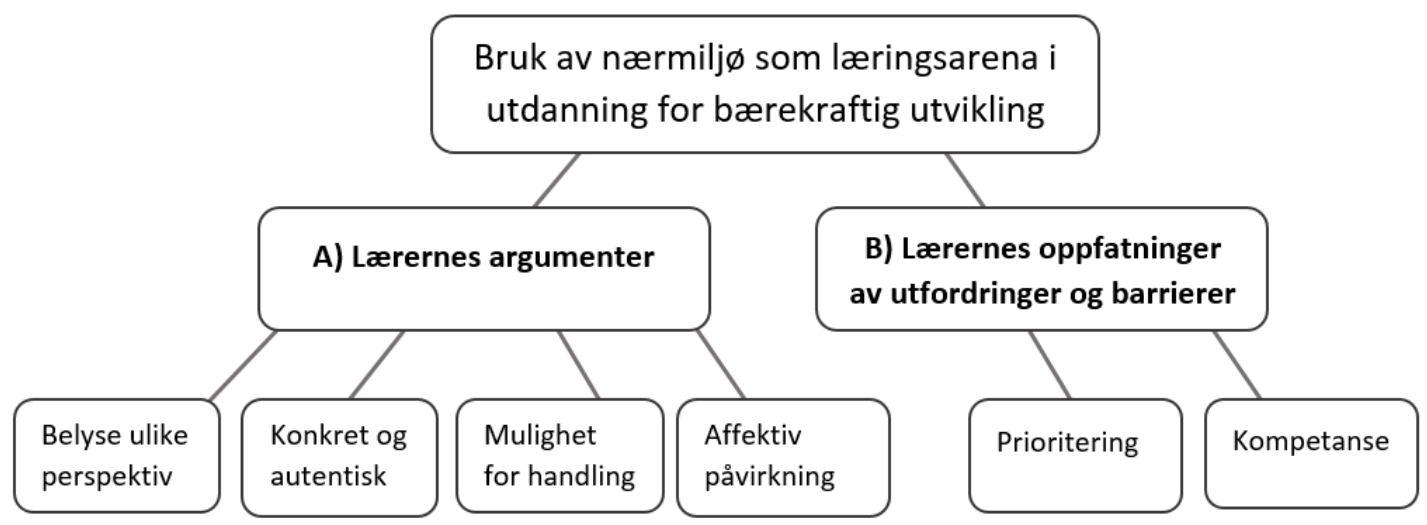

Figur 1. Modell som viser de to hovedretningene A og B, konstruert ved hjelp av sammenhenger mellom innledende koder, fokuserte koder og foreløpige kategorier. 


\section{Drøfting}

På bakgrunn av den beskrevne analysen drøftes forskningstilnærmingens bidrag til å få fram nye perspektiv som kan brukes til utvikling av undervisningspraksis og til videre teoridanning og forskning. Det fokuseres spesielt på nærhet til lærernes utsagn, konstruktivistisk kunnskapsdanning, systematisering av ordrikt datamateriale og praksisnær teoridanning.

\section{Nærhet til lærernes utsagn}

Innsamling av data via semi-strukturerte intervju ga lærerne anledning til å være med å styre samtalen og vektlegge sider ved praksis de mente var sentrale. Dette er et godt utgangspunkt for en forskningstilnærming hvor målet er å få fram nye perspektiv med røtter i praksis. Dataene blir i denne sammenheng mer interessante når de i sterkere grad representerer lærernes stemmer enn det som ville kommet fram i et mer styrt og strukturert intervju eller i forhåndsdefinerte svarkategorier i en spørreundersøkelse (Brinkmann \& Kvale, 2015; Charmaz, 2014; Creswell, 2013).

I analysen var forbindelsen til dataene spesielt tydelig i den innledende kodingen som i stor grad var preget av deltakernes egne ord. En fordel med denne måten å kode på har vært muligheten for å fange opp synspunkt og ideer som kunne unnsluppet hvis data hadde blitt bearbeidet ved hjelp av en analyse hvor analysekategoriene enten ville vært definert ut fra intervjuguiden eller blitt konstruert i et tidlig stadium av analysen. Charmaz (2014) sammenlikner koding med å skape knokler og skjelett som kan brukes til analyse, og at koding er mer enn «en begynnelse», den former en analytisk ramme som du bygger din analyse på (Charmaz, 2014, s. 113). Under den innledende kodingen er målet å være åpen for de mulige retningene dataene kan lede oss i. Hva jeg ser i dataene og hvordan jeg tolker dem, vil likevel avhenge av eget perspektiv og tidligere erfaringer. Jeg hadde med meg antakelser for hva jeg kunne forvente av sentrale tema både under utforming av intervjuguiden og ved gjennomgang av intervjuene. For eksempel at lærerne syns undervisning for bærekraftig utvikling er utfordrende, noe som er basert på egen erfaring fra undervisning og veiledning innen tematikken.

Under den fokuserte kodingen ble det foretatt et utvalg på bakgrunn av de innledende kodenes frekvens eller hvor betydningsfulle de var for studiens problemstilling. Selv om også denne fasen ble forsøkt holdt nært opp til lærernes egne utsagn, er den en prosess som tydelig preges av forskerens valg, og er derfor i større grad forskerens stemme. For eksempel blir den innledende koden «utvide området» plassert i den fokuserte koden «lokal - regional - global». Dette valget er basert både på en forforståelse av UBU-teori knyttet til lokalglobal-perspektivet, men også i stor grad på rådataene og sammenhengen i hele intervjuet. Når denne læreren sier «vi må bare gjøre sirklene større og større, gå lenger og lenger ut», så kan dette settes i sammenheng med deres under- 
visningsprosjekt som startet med veldig lokale aktiviteter og problemstillinger for så å ta inn mer regionale, nasjonale og globale utfordringer innen samme tematikk.

Overgangen mellom innledende og fokuserte koder har vært både enkel og utfordrende. Noen fokuserte koder falt relativt raskt på plass, mens andre måtte gjennom mange runder med utprøving av både fokuserte koder og begynnende kategorier før de ga mening. I denne fasen ble de fokuserte kodene og kategoriene flyttet rundt i store Excel-ark, samtidig som de ble sammenliknet med innledende koder og rådata. I memoer fra den tidlige fasen av fokusert koding står det blant annet: «Hva er sentralt? Sliter med å nedprioritere, alt føles viktig.» Spørsmålet er da i hvilken grad det er mulig å beholde «lærerens stemme» samtidig som det fokuseres og systematiseres? Vil studiens målsetting, med forskerens erfaringer og ønsket retning, uansett styre tolkningen av rådataene inn i en nærmest forhåndsbestemt retning? Selv om intensjonen har vært å møte datamaterialet med et åpent sinn for å fange opp mest mulig av lærernes perspektiv, blir analysen og tolkingen preget av tidligere erfaringer og forforståelse (Charmaz, 2014; Postholm, 2010). Samtidig er det nettopp denne bakgrunnen som gir nødvendig grunnlag for å kunne se og konstruere abstrakte sammenhenger ut fra de konkrete dataene.

I en memo skrevet i fasen med kategorisering av fokuserte koder, er det tydelige utfordringer knyttet til innholdet i kategorien «Læringsutbytte og vurdering»: «Kategorien kan forstås på flere måter. Å bruke de fokuserte kodene holder ikke. Må tilbake til sammenhengen de er hentet fra og kanskje lage ny kategori?» Dette kan illustrere hvordan den gjentakende sammenlikningen mellom rådata, koder og kategorier i stor grad bidrar til å holde tolkningene nær opp til det som ble sagt i intervjuene. Selv om kodene abstraheres og settes i system, kontrolleres sammenhengen de er tatt ut fra i flere omganger.

\section{Konstruktivistisk syn på kunnskapsdanning}

Grounded theory har blitt kritisert for sine positivistiske trekk hvor forskeren går inn i analysen med et åpent sinn, for å være empirinær, og hvor det søkes objektiv kunnskap gjennom empirisk datainnsamling. I analysen av lærernes undervisningserfaringer vektlegges derimot deres subjektive opplevelse, som avhenger av læreren, elevene og i tillegg den lokalt tilpassede undervisningen med bruk av autentiske og aktuelle problemstillinger. Ikke bare opplevelsen av undervisningen, men også forståelsen av fagtemaet bærekraftig utvikling, vil med de ulike dimensjonene knyttet til samfunn, økonomi, natur, lokalt, globalt, nåtid og framtid vanskelig kunne analyseres ut fra en forståelse av objektiv kunnskap, da de ulike perspektivene vil avhenge av både lærerens og forskerens eget perspektiv.

Kritikerne av en rendyrket, klassisk grounded theory har pekt på det umulige ved å gjennomføre en induktiv analyse, hvor datamaterialet «taler for seg» og forskerens egen forforståelse i liten grad påvirker resultatet (Charmaz, 2014; 
Postholm, 2010; Thornberg, 2012). Grounded theorys rykte som positivistisk og naiv empiristisk, kan være mer eller mindre fortjent, selv om heller ikke Glaser og Strauss mente at forskeren skulle gå inn i analysen med «et tomt hode», noe som kommer fram i deres senere tekster, men også i deres opprinnelige bok fra 1967: «Of course, the researcher does not approach reality as a tabula rasa. He must have a perspective that will help him see relevant data and abstract significant categories from his scrutiny of the data» (Glaser \& Strauss, 1967, s. 3).

De kategoriene og fokuserte kodene som til slutt ble resultatet og brukes som grunnlag for modellen i figur 1, er ikke den eneste rette løsningen. Det er foretatt mange valg underveis i forskningsprosessen med bakgrunn i vurdering av rå, kontekst og foreløpige koder og kategorier. Dette er i overensstemmelse med den konstruktivistiske retningen av grounded theory hvor det ikke søkes etter objektive fakta som kan oppdages, men forståelse som skapes av forskeren i samspill med praksisfeltet, hvor forskerens tolking og perspektiv ses på som ett av flere, og ikke den eneste sannhet (Charmaz, 2014; Silverman, 2011).

\section{Systematisering av datamaterialet}

Det innsamlede datamaterialet fra intervjuene var omfattende og ordrikt, og det var derfor et mål å finne ut hvordan analysemetoden bidrar til å skaffe oversikt og systematisere. Innledende koding resulterte i et stort antall koder, mens fokusert koding bidro til å trekke fram de mest frekvente og/eller sentrale kodene, noe som påskyndet analysen gjennom utvalg og fokusering. Og nettopp det å komme i gang og få fart på analysen er en god grunn for å benytte grounded theory. Charmaz (2014) mener metoden bidrar til analytisk kontroll og framdrift og rett og slett avmystifiserer gjennomføringen av kvalitative undersøkelser, og hun sier: «Grounded theory strategies will help you get started, stay involved, and finish your project» (Charmaz, 2014, s. 3).

Anvendelse av koding og den konstant komparative analysen har vært tidkrevende ved at dataene ble gransket nøye i flere omganger, og det ble hele tida gjort avveininger om sammenhenger og relevans. Samtidig kan denne tilnærmingen ha bidratt til å øke analysens validitet ved at sentrale aspekter faktisk fanges opp, selv om materialet reduseres og systematiseres. Silverman (2011, s. 393) peker på konstant komparativ analyse og aktivt søk etter avvikende tilfeller som effektive verktøy for å øke analysens validitet og for å unngå anekdotisk kvalitativ forskning.

Kategoriseringen gir en oversikt over resultatene; samtidig blir helheten i intervjuene oppdelt, og konteksten knyttet til hvem, hvor og når er ikke lenger synlig. En utfordring med dette er at mange av de opprinnelige kodene kan forstås ulikt avhengig av sammenhengen de står i, noe som har betydning for UBU-tematikken som er nært knyttet til sted og tid. Helhetsforståelsen som ligger i de opprinnelige dataene kan likevel ivaretas også under kategoriseringen ved at ikke bare de mer abstrakte, fokuserte kodene benyttes, men også 
rådataene og de innledende kodene som i stor grad er lærernes egne ord. For eksempel kan den fokuserte koden «sammenhenger» tolkes i flere retninger hvis den står alene. Hvis den derimot ses i forbindelse med den innledende koden «lettere å forstå» og rådataene «og da mener jeg det blir lettere og lettere å forstå og elevene skjønner mer av sammenhengene» (tabell 1 og 2) gir den mening som er nært opp til det læreren snakket om. Når kategorien «belyse ulike bcerekraftsperspektiv» konstrueres og tar opp i seg den fokuserte koden «sammenhenger» (tabell 3), gjøres dette etter vurderinger også av innholdet i rådataene og innledende kode og en sammenlikning av andre koder med liknende innhold. I denne prosessen har det vært nyttig å jevnlig skrive ned tanker om forbindelser mellom koder og kategorier, i form av memoer.

Analysen har blitt gjennomført av samme forsker som intervjuet lærerne på deres arbeidsplass og som transkriberte lydfilene i etterkant. Denne nærheten til datamaterialet er også med på å ivareta betydningsfull kunnskap om konteksten bak de forenklede kodene, noe som gir den mer abstrakte kategoriseringen og modelleringen korrektiv i retning av lærernes utsagn.

Samtidig som det er nyttig å få oversikt over resultatene gjennom å sette sammen kategoriene til en foreløpig modell (figur 1), gir også den grundige undersøkelsen av de enkelte delene, de enkelte kategoriene, en dypere helhetsforståelse. Dette er et poeng som vektlegges av Postholm i hennes beskrivelse av analyse i kvalitativ forskning: «Hensikten med en slik oppdeling er ikke fortrinnsvis å forstå de ulike delene bedre. Men en bedre forståelse av de enkelte delene kan bidra til en dypere, helhetlig forståelse av fenomenet eller settingen som er studert» (Postholm, 2010, s. 105). Det gjelder også i denne studien, hvor det er mange faktorer som påvirker en kompleks undervisningspraksis. Det er derfor et mål å få til en helhetlig drøfting hvor sentrale funn innenfor kategorier settes sammen for å få fram sammenhenger.

\section{Begynnende teoridanning}

Et mål med selve intervjustudien har vært at det som forskes på skal ha røtter i praksis og bety noe for praksis, men likevel løftes opp på et mer abstrakt nivå. Det er derfor også et mål å finne ut hvordan forskningstilnærmingen kan bringe fram nye perspektiv og medvirke til begynnende teoridanning. Selv om det i flere tiår har vært gjennomført undervisning innen miljøtema i norsk skole (Sandås \& Isnes, 2015), har denne praksistradisjonen i liten grad blitt forsket på, og det foreligger derfor begrenset teori med kopling til praksis som er relevant for norske forhold. Også internasjonalt er det få empiriske studier knyttet til læreres erfaring og perspektiv på egen undervisningspraksis innen UBU (Blum et al., 2013; McNaughton, 2012; Reid \& Scott, 2013).

Kategoriene (se figur 1 og tabell 3) som er blitt konstruert gjennom gjentakende sammenlikning av fokuserte koder, innledende koder og rådata, er et abstrahert, men likevel praksisnært rammeverk. Det kan ses på som del av kontekstbundet substantiv teoridanning (Charmaz, 2014; Postholm, 2010), og kan 
brukes som grunnlag for videre forskning og som utgangspunkt for utvikling av praksis. Det konkrete rammeverket med kategorier og fokuserte koder videreutvikles gjennom drøfting av utdanningspolitikk og teori innen UBU og bruk av nærmiljø som læringsarena (Gabrielsen \& Korsager, under utgivelse).

Lærerperspektivet, som ivaretas gjennom den valgte analysetilnærmingen, kan bidra til et skifte i fokus fra abstrakt utdanningspolitikk og teori om hva UBU bør være, til et fokus på kontekstualiserte praksiser. Gudmundsdottir (1992) peker på det å beskrive lærernes praksisteori som en av de største oppgavene for kvalitative forskere innen pedagogikk. Denne praksiskunnskapen, som stort sett er ubevisst og automatisk, blir gjennom forskerens systematikk og tolkning belyst og bevisstgjort ved «å gjøre det ubevisste bevisst» (Gudmundsdottir, 1992). Lærernes erfaringer med UBU er gjennom analysetilnærmingen blitt løftet fram og kan bidra inn i kunnskapsproduksjonen i et forskningsfelt hvor det er behov for å styrke bindeleddet mellom teori, politiske retningslinjer og implementering.

\section{Konklusjon}

Grounded theory har operert i forskningssamfunnet i over 50 år, og blir fortsatt mye benyttet innen kvalitativ forskning. I denne metodologistudien drøftes anvendelse av konstruktivistisk grounded theory (Charmaz, 2014) på et datamateriale med intervjuer av lærere med erfaring i UBU. I analysen var forbindelsen til rådataene spesielt tydelig i den innledende kodingen som i stor grad var preget av deltakernes egne ord. Under den fokuserte kodingen ble det foretatt utvalg på bakgrunn av de innledende kodenes frekvens eller hvor betydningsfulle de var for studiens problemstilling. Selv om også denne fasen ble forsøkt holdt nært opp til lærernes egne utsagn, preges den tydeligere av forskerens valg, og er derfor i større grad forskerens stemme. Et dilemma er derfor hvorvidt det er mulig å beholde «lærerens stemme» samtidig som datamaterialet abstraheres. De fokuserte kodene ble videreutviklet til kategorier og en begynnende modell, blant annet ved hjelp av memoer med tolkning av kodene. I denne analysetilnærmingen er det et poeng at kategoriene ikke fastsettes tidlig i prosessen, for eksempel på bakgrunn av intervjuguiden, men heller bestemmes etter omfattende koding og komparativ analyse. Analyseprosessen har vært tidkrevende, og det har vært utfordrende å prioritere og trekke ut hva som er mest sentralt. Samtidig kan denne tilnærmingen bidra til å øke analysens validitet ved at sentrale aspekter faktisk fanges opp, selv om materialet reduseres og abstraheres. De intervjuede lærernes erfaringer med UBU er gjennom analysetilnærmingen i stor grad blitt løftet fram og kan bidra inn i kunnskapsproduksjonen i et forskningsfelt hvor det er behov for å styrke bindeleddet mellom teori, politiske retningslinjer og implementering. I Stortingsmelding 28 om fornyelse av Kunnskapsløftet vektlegges både opplæringssystemets ansvar 
for å gi elevene kompetanse for en bærekraftig utvikling og et utviklingsorientert lærerkollegium som reflekterer over forskningsbasert kunnskap kombinert med erfaringer fra egen praksis (Meld. St. 28, 2015-2016). UBU er et utfordrende emne, hvor holdninger, følelser og handlinger må inkluderes i undervisningen, i tillegg til kunnskap og ferdigheter. Lærerne har i liten grad vært med på å forme bærekraftbegrepet og utdanningsmålene, men er de som leder læringsprosessene i skolen. De bør derfor i sterkere grad involveres i UBU-diskursen og produksjon av teori som er relevant for utvikling av deres undervisning. Målet med denne studien har vært å vise hvordan en forskningstilnærming kan bidra til å framskaffe relevant kunnskap med utgangspunkt i praksis innenfor et nytt satsingsområde i skolen.

\section{Om forfatteren}

Anja Gabrielsen er ph.d-stipendiat og universitetslektor i naturfagdidaktikk ved Universitetet i Sørøst-Norge. Hennes forskningsinteresser omfatter blant annet utdanning for bærekraftig utvikling, bruk av uteundervisning og naturfagdidaktikk.

Institusjonstilknytning: Institutt for matematikk og naturfag , Fakultet for humaniora, idretts- og utdanningsvitenskap, Universitetet i Sørøst-Norge, Kjølnes ring 56, 3918 Porsgrunn.

E-post: anja.gabrielsen@usn.no

\section{Referanser}

Alvesson, M. \& Sköldberg, K. (2008). Tolkning och reflektion - vetenskapsfilosofi och kvalitativ metod (2. utg.). Lund Studentlitteratur.

Blum, N., Nazir, J., Breiting, S., Goh, K. C. \& Pedretti, E. (2013). Balancing the tensions and meeting the conceptual challenges of education for sustainable development and climate change. Environmental Education Research, 19(2), 206-217. doi: https://doi.org/10.1080/13504622.2013.780588

Borg, C., Gericke, N., Höglund, H.-O. \& Bergman, E. (2012). The barriers encountered by teachers implementing education for sustainable development: discipline bound differences and teaching traditions. Research in Science \& Technological Education, 30(2), 185-207. doi: https://doi.org/10.1080/02635143.2012.699891

Breiting, S. \& Wickenberg, P. (2010). The progressive development of environmental education in Sweden and Denmark. Environmental Education Research, 16(1), 9-37. doi: https://doi.org/10.1080/13504620903533221

Brinkmann, S. \& Kvale, S. (2015). InterViews: Learning the Craft of Qualitative Research Interviewing (3. utg.). Thousand Oaks, Calif Sage.

Charmaz, K. (2000). Grounded theory: Objectivist and constructivist methods. I N. Denzin \& Y. Lincoln (red.), Handbook of qualitative research (2. utg.) (s. 509-535). Thousand Oaks: CA: Sage.

Charmaz, K. (2014). Constructing grounded theory (2. utg.). London: Sage. 
Corbin, J. \& Strauss, A. (2008). Basics of Qualitative Research: Techniques and Procedures for Developing Grounded Theory (3. utg.). Thousand Oaks: SAGE Publications, Inc.

Creswell, J. W. (2013). Qualitative inquiry \& research design. Choosing among five approaches (3. utg.). Los Angeles: Sage.

Denzin, N. K. \& Lincoln, Y. S. (2011). Introduction. The Discipline and Practice of Qualitative Research. I N. K. Denzin \& Y. S. Lincoln (red.), The SAGE Handbook of Qualitative Research (4. utg.) (s. 1-43). Thousand Oaks, CA: Sage.

Dobson, A. (1996). Environment sustainabilities: An analysis and a typology. Environmental Politics, 5(3), 401-428. doi: https://doi.org/10.1080/09644019608414280

Gabrielsen, A. \& Korsager, M. (under utgivelse). Nærmiljø som læringsarena i undervisning for bærekraftig utvikling. En analyse av læreres erfaringer og refleksjoner. Nordina. Akseptert for publisering.

Glaser, B. G. \& Strauss, A. L. (1967). The Discovery of Grounded Theory: Strategies for qualitative research. New York: Aldine de Gruyter.

Gudmundsdottir, S. (1992). Den kvalitative forskningsprosessen. Norsk pedagogisk tidsskrift, 5, 266-276.

Laurie, R., Nonoyama-Tarumi, Y., Mckeown, R. \& Hopkins, C. (2016). Contributions of Education for Sustainable Development (ESD) to Quality Education: A Synthesis of Research. Journal of Education for Sustainable Development, 10(2), 226-242. doi: https://doi.org/doi:10.1177/0973408216661442

McNaughton, M. J. (2012). Implementing Education for Sustainable Development in schools: learning from teachers' reflections. Environmental Education Research, 18(6), 765-782. doi: https://doi.org/10.1080/13504622.2012.665850

Meld. St. 28 (2015-2016). Fag - Fordypning - Forståelse. En fornyelse av Kunnskapsløftet. Hentet fra https://www.regjeringen.no/no/dokumenter/meld.-st.-28-20152016/id2483955/

NOU 2015:8 (2015). Fremtidens skole. Fornyelse av fag og kompetanser. Hentet fra https://www.regjeringen.no/contentassets/da148fec8c4a4ab88daa8b677a700292/no/pdfs/ nou201520150008000dddpdfs.pdf

Postholm, M. B. (2004). Kvalitativ forskning på praksis. Fra opprinnelse til forskerfokus. Norsk pedagogisk tidsskrift, 88(01), 3-18.

Postholm, M. B. (2010). Kvalitativ metode. En innføring med fokus på fenomenologi, etnografi og kasusstudier. Oslo: Universitetsforlaget.

Reid, A. \& Scott, W. (2013). Identifying needs in environmental education research. I R. B. Stevenson, M. Brody, J. Dillon \& A. E. J. Wals (red.), International Handbook of Research on Environmental Education (s. 518-528). New York: Routledge Publishers.

Sandås, A. \& Isnes, A. (2015). Utdanning for bærekraftig utvikling. KIMEN, (1), 1-66.

Scheie, E. (2014). Den naturlige skolesekken. Naturfag, (2), 8-11.

Silverman, D. (2011). Interpreting qualitative data (4. utg.). Sage Publications Ltd.

Sinnes, A. T. (2015). Utdanning for bcerekraftig utvikling. Hva, hvorfor og hvordan? Oslo: Universitetsforlaget.

Stevenson, R. B. (2006). Tensions and transitions in policy discourse: recontextualizing a decontextualized EE/ESD debate. Environmental Education Research, 12(3-4), 277-290. doi: https://doi.org/10.1080/13504620600799026

Stevenson, R. B. (2007). Schooling and environmental education: contradictions in purpose and practice. Environmental Education Research, 13(2), 139-153. doi: https://doi.org/10.1080/13504620701295726

Stevenson, R. B., Brody, M., Dillon, J. \& Wals, A. E. J. (2013). An Orientation to Environmental Education and the Handbook. I R. B. Stevenson, M. Brody, J. Dillon \& A. E. J. Wals (red.), International Handbook of Research on Environmental Education (s. 16). New York: Routledge Publishers. 
Thornberg, R. (2012). Informed Grounded Theory. Scandinavian Journal of Educational Research, 56(3), 243-259. doi: https://doi.org/10.1080/00313831.2011.581686

UNESCO (2005). UN Decade of Education for Sustainable Development (2005-2014). The DESD at a glance. Paris. Hentet fra http://unesdoc.unesco.org/images/0014/001416/141629e.pdf 